\title{
Utilization of the Wondershare Filmora Application in Compiling Arabic Teaching Materials Based on Local Culture
}

\author{
Nur Agung ${ }^{1}$, Amran $\mathrm{AR}^{2}$, Husnaini Jamil ${ }^{3}$ \\ \{comaagung@gmail.com ${ }^{1}$ \} \\ Institut Agama Islam Muhammadiyah Sinjai, Sulawesi Selatan, Indonesia ${ }^{1,2,3}$
}

\begin{abstract}
Arabic is one of the international languages that is widely studied and used in various parts of the world, including Indonesia. The government determines Arabic as a foreign language that must be mastered by students who study in Islamic-based educational institutions, such as Islamic universities. There are many obstacles that occur in the field related to the Arabic learning process, including the unsuitability of the teaching materials used with the situations and conditions of students. The use of video editing applications such as Wondershare Filmora is expected to improve the ability of students in Arabic, especially combined with a local cultural approach in the process of compiling teaching materials. The preparation of Arabic teaching materials based on local culture utilizes the Wondershare Filmora application in its presentation process with the aim of increasing students' interest and ability to speak Arabic. This study uses the Research and Development method by carrying out the method proposed by Borg and Gall. With the preparation of Arabic teaching materials which contain local culture-based material and compiled using the Wondershare Filmora application, it is hoped that students will be able to use simple Arabic in daily communication or as the language of instruction in the learning process.
\end{abstract}

Keywords: Arabic teaching materials, wondershare filmora, local culture, arabic language learning, interactive learning videos

\section{Introduction}

Arabic as one of the major languages in the world spoken by approximately 200 million people of the world has been present in Indonesia since several centuries ago as the entry and spread of Islam in Indonesia. The position of Arabic for Indonesian people is like Indonesian as the first language, it is integrated with the life of the majority of Indonesians who are Muslims, because it is undeniable that Arabic is the language of the Holy Qur'an [1].

The existence of Arabic language is very significant, causing many educational institutions both formal, non-formal, and informal require their students to learn every aspect related to Arabic. Starting from grammar, mastery of language skills to being able to communicate in Arabic.

One educational institution that requires its students to master Arabic is the Islamic College. Not only students from Arabic language courses, but all students from various courses regardless of their educational background [2]. There are many challenges faced by educators and students during the Arabic learning process, especially by IAIM Sinjai students. There are 
several problems that become major obstacles for them in mastering Arabic, including: the use of traditional learning media (books and blackboards), the lack of use of available learning facilities and infrastructure, and the content of teaching materials that are far from student life.

The development of technology-based teaching materials becomes a necessity so that the learning process can continue properly. In addition, materials or teaching materials presented with the proper use of technology is considered to be able to increase the motivation of students in following the learning and accelerate the understanding and mastery of the material set [3]. The presence of Covid-19 in Indonesia since 2020 has also added to problems in the learning process. The learning process, which could initially be carried out face-to-face, must be replaced with online learning. This model of learning system "forces" educators and students to master various cutting-edge learning technologies. As explained Wildana et al in their journal [3]. Many applications can be used for the preparation of interactive teaching materials, either in the form of audio, visual, or audio visual. One of them is Wondershare Filmora, a software or video editor application designed to create videos simply and easily [4]. In this application there are various tools that can be used by educators to develop an interactive material, such as creating interesting intros, adding videos, images and backsound that can be combined to become a learning video that is able to deliver materials effectively and efficiently.

The majority of Arabic teaching materials in Indonesia, especially for the college level are still oriented towards teaching materials originating from the Middle East such as Al 'Arabiyyah Baina Yadaik. The use of this teaching material poses its own problems for students, namely the difficulty of the process of using materials in the daily communication process, because many of the vocabulary and expressions used are not in accordance with the situation and conditions of students in Indonesia. This condition makes contextual approach important to be considered in the process of preparation of teaching materials. One type of contextual approach that can be utilized is the use of local cultural elements in the content of the material to be presented, both in the form of audio, visual and audio visual [5]. Based on the various conditions and problems above, it can be understood that learning in this pandemic era can be carried out optimally by using appropriate technology, such as for the preparation of audio-visual based teaching materials by utilizing the Wondershare Filmora application. In addition, to achieve the goal of learning Arabic as a communication tool, the use of local cultural elements in the preparation of local culture is expected to be one of the many solutions to improve the quality of Arabic language education in Indonesia. Therefore, this study aims to determine the effect of the use of the Wondershare Filmora application in the preparation of Arabic language teaching materials based on local culture.

\section{Method}

This type of research is research that combines qualitative and quantitative or R\&D approaches. The development of this teaching material is carried out by following the development flow of Borg and Gall which consists of 10 steps. However, researchers only use a few steps, namely (1) Needs Analysis (2) Planning, (3) Design Development (4) Trial (5) Revision (6) Trial and (7) Final Revision. The development flow proposed by Borg and Gall is expected to be able to assist researchers in compiling valid teaching materials according to student needs. This product was tested to students of Islamic Religious Education study program Of Muhammadiyah Sinjai Islamic Institute with a total of 27 people. Research data collected using several research instruments, namely observation, interview, and test. Observations and 
interviews are conducted to find out the response of research objects to the products developed. The test was conducted twice, namely pre-test and post-test to find out the success rate of teaching materials in improving students' understanding of Arabic.

\section{Result and Discussion}

\subsection{Results}

Based on the observations and interviews at the beginning of the study, it is known that students use teaching materials published in Medina. This book is compiled for non-Arabic in general and uses Arabic as the language of instruction, whereas the majority of students do not yet have a basis in Arabic, so they have difficulty in using the book let alone understand it (see Figure 1). This book consists of several parts, but pai students at IAI Muhammadiyah Sinjai only use the first part (see Figure 2).

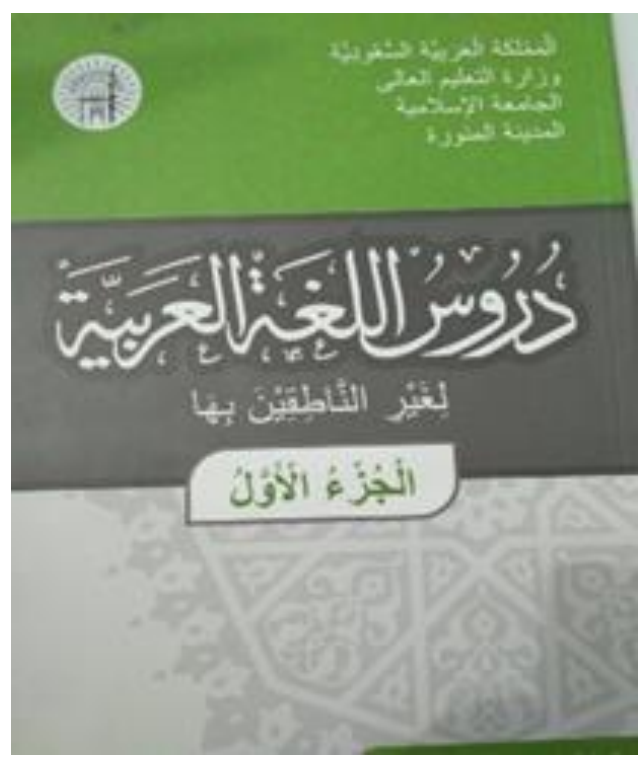

Fig. 1. Arabic Teaching Materials

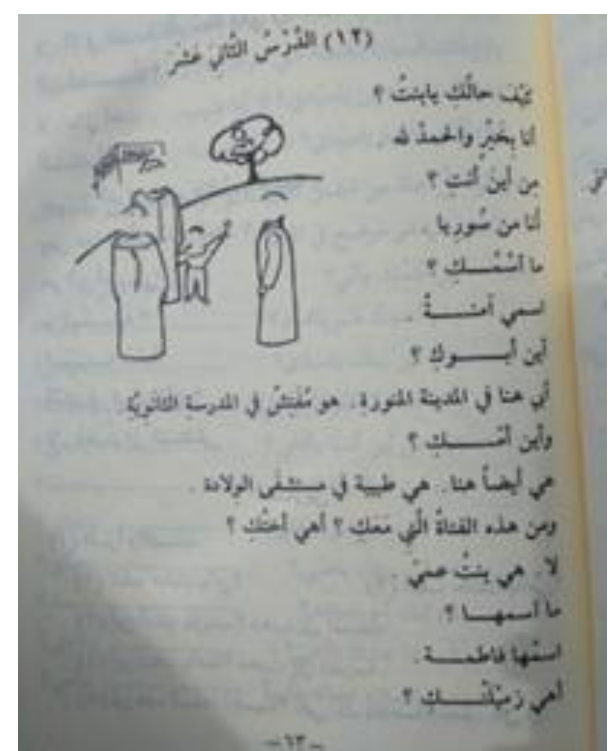

Fig. 2. Sample Conversation

The picture above shows an example of an Arabic conversation discussing a person's home region. One of the areas mentioned is Syria and Madinah Munawwarah (see Figure 3). This teaching material intended for non-Arabic uses Arabic as the language of instruction in all parts of the material, so that novice learners have difficulty in understanding the content of the material (see Figure 4). The material is arranged by prioritizing aspects of local culture, namely by including objects, habits, names, and circumstances commonly encountered by everyday students (see Figure 5). 


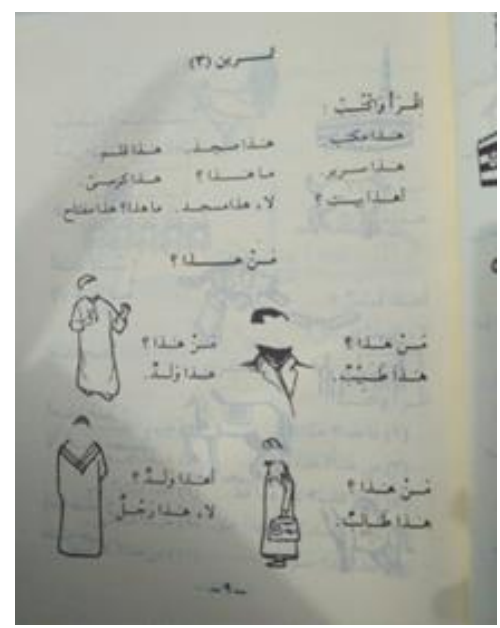

Fig. 3. Introductory Language spoken

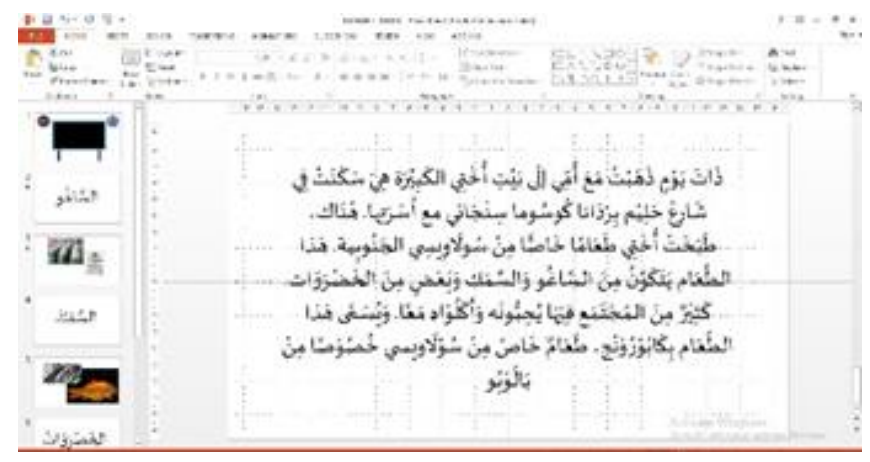

Fig. 4. Material Development Results

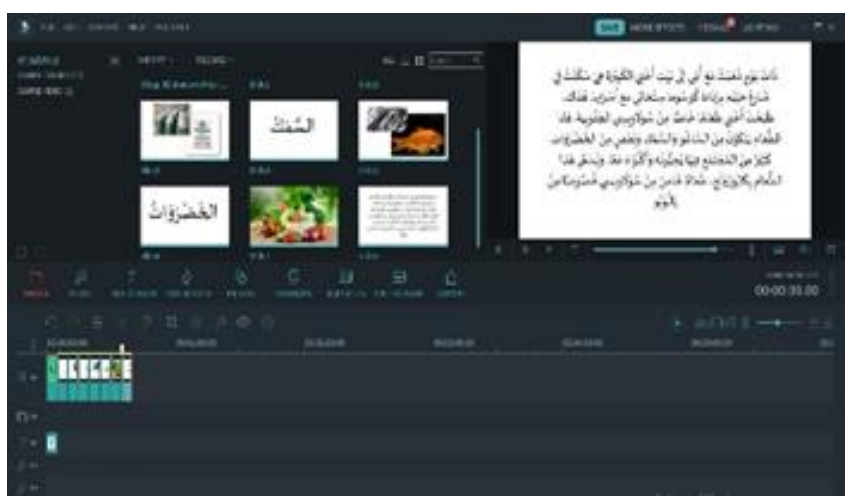

Fig. 5. Video Editing Process 
The material that has been prepared before is combined and edited by using wondershare filmora application to produce an interactive learning video that can be used to deliver the material during online learning.

Based on pre-test and post-test tests conducted on PAI IAI Muhammadiyah Sinjai students, it is said that there is a significant influence on students' Arabic learning outcomes by using materials presented in the form of interactive teaching videos.

Pre-test and post-test test results are analyzed using Paired Samples T Test test contained in SPSS 20 application (See Table 1).

Table 1. Pre-test and post-test results

\begin{tabular}{|c|c|c|}
\hline No & Pre-Test & Post-Test \\
\hline 1 & 65 & 78 \\
\hline 2 & 67 & 80 \\
\hline 3 & 60 & 80 \\
\hline 4 & 70 & 80 \\
\hline 5 & 77 & 86 \\
\hline 6 & 75 & 90 \\
\hline 7 & 70 & 85 \\
\hline 8 & 79 & 85 \\
\hline 9 & 70 & 85 \\
\hline 10 & 65 & 80 \\
\hline 11 & 65 & 85 \\
\hline 12 & 68 & 80 \\
\hline 13 & 60 & 75 \\
\hline 14 & 60 & 79 \\
\hline 15 & 75 & 80 \\
\hline 16 & 75 & 80 \\
\hline 17 & 80 & 89 \\
\hline 18 & 75 & 85 \\
\hline 19 & 80 & 85 \\
\hline 20 & 86 & 90 \\
\hline 21 & 86 & 95 \\
\hline 22 & 70 & 85 \\
\hline 23 & 70 & 80 \\
\hline 24 & 75 & 80 \\
\hline 25 & 60 & 80 \\
\hline 26 & 60 & 85 \\
\hline 27 & 65 & 80 \\
\hline
\end{tabular}

Table 2. Paired samples statistics

\begin{tabular}{lllll}
\hline & \multicolumn{4}{c}{ Paired Samples Statistics } \\
& Mean & N & Std. Deviation & Std. Error Mean \\
\hline Pair 1 & Pre test 70,67 & 27 & 7,766 & 1,495 \\
& Post 83,04 & 27 & 4,485 &, 863 \\
& test & & & \\
\hline
\end{tabular}


Table 3. Paired samples correlations

\begin{tabular}{lllll}
\hline \multicolumn{5}{c}{ Paired Samples Correlations } \\
& & N & Correlation & Sig. \\
\hline Pair 1 & $\begin{array}{l}\text { Pretest \& } \\
\text { Posttest }\end{array}$ & 27 &, 709 &, 000 \\
\hline
\end{tabular}

Table 4. Paired Samples Test

\begin{tabular}{lllll}
\hline \multicolumn{4}{l}{ Paired Samples Test } \\
\multicolumn{1}{l}{} & \multicolumn{1}{l}{ Df } & Sig. (2-tailed) \\
\hline Pair 1 & $\begin{array}{l}\text { Pretest - } \\
\text { Posttest }\end{array}$ & $-11,543$ & 26 &, 000 \\
\hline
\end{tabular}

Based on the results of the Paired Samples Test on Table 4, it can be known that the use of Arabic teaching materials designed by utilizing the wondershare filmora application and incorporating local cultural elements is able to give a significant influence on the learning outcomes of PAI IAI muhammadiyah Sinjai students.

\subsection{Discussion}

The preparation of Arabic language teaching materials for non-Arabic language education study programs using wondershare filmora application combined with local cultural approach is able to improve students' understanding and ability in using Arabic as a simple communication language. This result is in accordance with what Andrea Hall stated in her article that the use of interactive applications, both in the form of learning videos and social media, is able to improve students' ability to master a material [6].

Wondershare Filmora app has a variety of simple features that can be understood and used by various circles. Among these features are (1) imported files that serve to add images, sounds or videos needed, (2) effects. This feature can be used to add an interesting impression of the video made, (3) Transition, which can be used to arrange various materials needed so that it looks natural and attractive. The existence of these features can be used to make the learning process more effective and enjoyable [7].

Local culture as part of contextual approach will give more meaning to students in understanding the material taught. This is because the material is in accordance with the lives and habits of students every day, such as the use of regional names, street names, food, and places around the student environment [8]. In addition, the use of mother tongue as an introductory language can help students who have no basis in Arabic to understand and apply the materials taught [9].

The use of learning videos designed with wondershare filmora application and local cultural approach received a positive response from students as seen from the results of pre-test and post-test tests that showed an increase in student learning outcomes after using interactive learning videos in the learning process. 


\section{Conclusion}

The use of wondershare filmora application and local cultural approach in the preparation of Arabic teaching materials for PAI IAI Muhammadiyah Sinjai students can improve the effect and efficiency of the Arabic learning process. Lecturers and other educators can use this application to increase students' learning desire and understanding of the materials studied, as well as to make students can learn according to the times that occur.

\section{Acknowledgements}

This research was supported by Lembaga Research and Community Service (LP2M) IAI Muhammadiyah Sinjai through research grants. Thank you to the various parties who have helped this research process from start to finish.

\section{References}

[1] S. Sauri, "Sejarah Perkembangan Bahasa Arab Dan Lembaga Islam," vol. 1, no. 8, pp. 9-20, 2008.

[2] A. Fatoni, U. M. Malang, D. Gontor, and N. Speakers, “صلختسم ثحبلا ناملك قيساساً ةمدقم," vol. 2, no. 2019 , pp. $149-164$.

[3] W. Wargadinata, I. Maimunah, and S. Ramadhanti, "Mediated Arabic Language Learning for Arabic Students of Higher Education in COVID-19 Situation ثحب لا صلختسم," Izdihar J. Arab. Lang. Teaching, Linguist. Lit., vol. 3, pp. 59-78, 2020.

[4] D. Erlansyah, "Interactive Learning Berbasis Multimedia Audio Vidio Dengan Wondershare Filmora Pada Mata Kuliah Komunikasi Visual,” J. Informanika, vol. 6, no. 2, pp. 92-98, 2020.

[5] A. Tanjung, "rgensi Pengembangan Bahan Ajar Geografi Berbasis Kearifan Lokal," J. Pendidik. Geogr., vol. 20, no. 1, pp. 24-29, 2015.

[6] A. Hall and J. Herrington, "The development of social presence in online Arabic learning communities," vol. 26, no. 7, pp. 1012-1027, 2010.

[7] Y. Bouato, F. Lihawa, and R. Rusiyah, "Pengembangan Media Pembelajaran Berbasis Sparkol Videoscribe Yang Diintegrasikan Dengan Wondershare Filmora Pada Mata Pelajaran Geografi Materi Mitigasi Bencana Alam,” Jambura Geo Educ. J., vol. 1, no. 2, pp. 71-79, 2020.

[8] Dek Ngurah Laba Laksana, Putu Agus Wawan Kurniawan, and Irama Niftalia, "Pengembangan Bahan Ajar Tematik Sd Kelas Iv Berbasis Kearifan Lokal Masyarakat Ngada,” J. Ilm. Pendidik., vol. 3, no. 1, pp. 1-10, 2016.

[9] T. Pransiska, "Buku Teks Al Lughah Al-'Arabiyah Al Muashirah bagi Penutur Non Arab, Konstruksi dan Implementasi,” Al-Fikra J. Ilm. Keislam., vol. 17, no. 1, 2018. 